\title{
DEVELOPING MODELS OF PROFESSIONAL COMPETENCE TO ENHANCE EMPLOYABILITY IN THE NETWORK WORLD
}

\author{
Professor Sheila Corrall \\ Professor of Librarianship \& Information Management \\ The University of Sheffield, \\ Department of Information Studies \\ Regent Court, 211 Portobello Street, Sheffield S1 4DP, UK \\ s.m.corrall@sheffield.ac.uk
}

\begin{abstract}
Key drivers of change today include rapid advances in computing and networking technologies, continuing growth of the information and knowledge economy and expectation of value-added personalised services. Related effects of environmental forces on the library and information profession include a convergence of interests around electronic delivery, a blurring of boundaries between professional specialisms and the emergence of composite services, combining libraries with other areas. Employment patterns and workplace practices have shifted towards project-based working and cross-functional teams. Vacancy advertisements for library and information workers reveal a wide range of job titles and a broader set of skills than sought historically in the sector. Research on skills needs and development priorities indicates that information professionals require a mix of specialist, generic, personal and contextualised knowledge and skills. Different models of professional competence are needed to help library and information professionals make sense of their position in the networked world, manage their own continuing development and define their unique contribution to their organisations and communities. Drawing on published literature and empirical evidence, this paper discusses the need for new conceptual frameworks and practical tools to enhance the employability of library and information professionals and presents some models developed for this purpose.
\end{abstract}

\section{Introduction}

Advances in information and communications technology (ICT) have transformed the workplace, education and society over the last ten years. Castells argues that the Internet provides both the technological basis and the organisational form - the network - for the 'Information Age'. ${ }^{1}$ Ward outlines how ICT has been the key driver of change for information professionals and has had an accelerator effect on other developments, such as globalisation, intensifying competition, the information 'explosion', potential democratisation of information ('information for all') and knowledge and information-based differentiation as a source of strategic advantage. ${ }^{2}$ Lynch explains that ICT previously enabled automation and innovation in libraries, but has recently brought about transformation with the provision of online content, which includes both 'born-digital' material and digital versions of legacy collections. $^{3}$

'Convergence' is a key phenomenon of the networked world. Johnson discusses convergence within the information industry which was traditionally divided into content creation (as in publishing and broadcasting), content delivery (as in libraries and bookselling) and content processing (as in typesetting and computing). Boundaries between previously separate sectors are blurring and many organisations are amalgamating previously separate activities, such as libraries, computing and publishing, under the same overall management. ${ }^{4}$ This trend is particularly prevalent in higher education in the US, ${ }^{5} \mathrm{UK}^{6}$ and Australia, ${ }^{7}$ and 
often extends beyond vertical integration of information-related functions to include horizontal integration with other areas where functions and activities overlap.

'Interdisciplinarity' and new multidisciplinary specialisms are influencing the development of the library and information profession. Coleman discusses the need to integrate other disciplines into professional education to prepare graduates for 'technologically rich workplaces'. 8 The Chartered Institute of Library and Information Professionals (CILIP) notes the emergence of health informatics, which integrates biomedical sciences, computer sciences and health care policy, as a 'key issue' for health librarians. Similarly, educational informatics has emerged at the intersection of information science, education and computer science, as a research field which is concerned with the relationships between people, information, ICT, learning and professional practice. ${ }^{10}$ McKnight reports a real-world example of multidisciplinary and multiprofessional convergence in the merger of a library with various educational support functions, including learning technology and academic staff development. ${ }^{11}$

Against this backdrop of technological and organisational change, the roles and skills of library and information professionals continue to evolve and develop, presenting challenges for both initial and continuing professional education and development. This paper draws selectively on published literature and job advertisements to examine the development of professional roles and identify patterns and trends. It reviews research and opinion on skills needed for the new environment and evaluates examples of competency frameworks against requirements identified. It presents some models of professional roles, competences and specialisms to illuminate the position of the profession and suggests further research to take this work forward.

\section{Developing roles - convergence and divergence}

There has been much discussion, reflection and speculation on the evolving roles of library and information professionals over the past decade, especially around the turn of the century, with many authors explicitly referring to new roles in their discourse. ${ }^{12}$ Some writers focus on the development of roles in specific sectors, notably the health sector in the context of evidence-based medicine $;^{13}$ others concentrate on one particular role, such as the teaching role of academic librarians. ${ }^{14}$ Another subset of the literature deals with opportunities for information professionals in related and emerging fields, such as competitive intelligence ${ }^{15}$ and knowledge management. ${ }^{16}$

A recurring theme in the literature is the threat of 'dis-intermediation' and consequent marginalisation or even extinction of the library or information centre, arising from Internetrelated developments and the 'end-user revolution'. In the academic sector, Bell and Shank identify several developments threatening the library's traditional position at the centre of information resource provision, including the promotion of courseware systems (also known as learning management systems or virtual learning environments) as the place where students access information resources for courses, and the establishment of institutional repositories as open archives where scholars can access research papers, rather than via the library's collections and services. ${ }^{17}$ Other practitioners see a vital role for libraries in contributing to such developments, in collaboration with teachers and researchers. ${ }^{18,19}$

The literature presents a confused picture of role development, with some sources underlining continuity and others emphasising change. In 2001, a survey of 947 American academic, school and public librarians identified the most significant roles of librarians for the next five years as follows:

- instructing users in the navigation and evaluation of print and digital information, 
- $\quad$ directing users to appropriate information resources,

- $\quad$ evaluating and purchasing resources for collection development,

- $\quad$ organising and cataloguing resources,

- $\quad$ creating programmes and services for under-served communities,

- $\quad$ creating new guides and/or navigational tools for electronic resources,

- $\quad$ archiving and digital preservation. ${ }^{20}$

Apart from the word 'digital' in two points, this list suggests that traditional roles associated with collection management and user support still dominate. Other sources reinforce this view. Braun points out that often "new roles are built on old ones"; ${ }^{21}$ Sharp argues that librarians can adapt established practices, such as selection, cataloguing, classification and instruction, for the networked information world; ${ }^{22}$ and Kwasik recognises that "technological demands significantly complicate the careers of [serials] librarians". ${ }^{23}$

However, some seminal reports have identified important and significant changes in the context of library and information work. A CILIP report on the implications of the knowledge-driven economy points to a broader concept of information management in organisations and blurred boundaries between the work of different professions. It defines 'information' as all content used in the context of an organisation, including "content in expertise databases; in learning programmes; in CRM, marketing and financial systems; in research reports and surveys; as well as in external information products and services”. It also sets out some diverse responsibilities associated with information management in this context:

- $\quad$ establishing information strategies, policies, standards, and good practices,

- $\quad$ creating enterprise wide information architecture enabling the integration of all internal and external information,

- $\quad$ managing the information flows within core business processes,

- $\quad$ supporting communities with highly relevant information,

- $\quad$ encouraging creativity through information,

- $\quad$ supporting the supply chain with content rich extranets.

CILIP notes that many professionals now have information-intensive roles and argues that "information management and specialisation is not the exclusive preserve of the information profession”. It sees a continuing need for an information-specialist profession, but as part of an information continuum or extended 'knowledge and information specialist community', which includes everyone who is engaged in the process of managing information. ${ }^{24}$

Similarly, CILIP's report on the health sector asserts that "the web has made a major impact on the way in which information is stored, retrieved and managed and has irrevocably altered the relationships among the information professional, the user and the content." It notes that some librarians have accordingly extended and redesigned their services, but others have lacked the organisational or personal capacity to do so, giving examples of contemporary roles and demands:

- $\quad$ Teaching - expansion and development of the role of librarians in user education, including classroom, point-of-need and online delivery,

- $\quad$ Searching - refinement and improvement of capability, particularly to support evidence-based practice,

- $\quad$ Outreach - increased proportion of work outside the library, often in multiprofessional and cross-functional teams,

- Knowledge - involvement in managing explicit and tacit knowledge, and in mapping the flow of knowledge and learning in organisations, 
- $\quad$ Technology - design and delivery of new electronic services, including content management systems, metadata and search functionality. ${ }^{9}$

Other authors confirm these trends, noting especially that librarians are often doing more complicated, difficult searches, with end-users doing their own basic searches. Some writers identify new or developed roles in publishing, including website and intranet management, ${ }^{25}$ advice, particularly on copyright and intellectual property, which is more complicated in the Internet era; ${ }^{26}$ and tailored or value-added information systems and services. $^{27}$

Several commentators mention the emergence of new specialisms or 'microspecialties' in information management - such as information architecture - as opportunities for professional development. ${ }^{28,29}$ CILIP also argues that information professionals in the health sector need to develop from generalists into specialists, possibly by training alongside other health professionals through placements, sabbaticals or attachments. ${ }^{9}$

\section{Recruitment evidence}

The recruitment sections of professional journals provide further evidence of new and evolving roles already available in library and information services. The 'Positions Open' pages of American Libraries and College \& Research Libraries News (US) and the 'Appointments' pages of Library + Information Gazette (UK) reveal a steady stream of jobs with the words 'electronic' or 'digital' in their titles, including both operational and developmental roles. Common examples include Electronic Resources Librarian and Digital Services Coordinator. There are also higher-level positions (such as Director of Digital Collections and Director for Digital Library Services) and project roles (for example, Digital Library Project Manager and Digital Initiatives Developer), in addition to posts specialising in metadata creation and in numeric and spatial data services, including geographic information systems.

Posts with an educational, instructional, training or learning role also feature prominently, both as add-ons to other roles (for example Reference/Instructional Librarian, Training \& Outreach Librarian) and as specialist roles of varying types (for example, Information Literacy Coordinator, Instructional Services Coordinator, Instructional Design Librarian, Instructional/Learning Technologist, Learning Adviser, Learning Support Librarian, Lifelong Learning Manager). The importance of this function is also shown by higher-level specialist roles, such as Head of Library Instruction, Director of Instructional Resources and Director of Educational Programs.

Another trend - more evident in the UK than in the US - is jobs with a focus on Knowledge Management (KM), such as Knowledge Manager, Knowledge Services Specialist, CRM \& KM Content Manager, Know-How Administrator, Head of Library \& Knowledge Services and Director of Knowledge \& Information Services. KM has also given new meaning to old roles, exemplified in the role of Community Librarians attached to 'communities-of-practice'.

\section{Trend analysis}

To understand the implications of such role developments, we need to go beyond the areas of development (such as teaching) and look at the nature of those developments. For example, in teaching, there is evidence of a broadening in scope, to cover computer skills and study skills, as well as subject-based information skills; an expansion of scale, with the role becoming part of more jobs, taking up more time and in some cases becoming a full-time specialism; and a deepening in content or complexity, with a requirement to integrate 
information-related instruction with the wider context of an educational curriculum or research project.

There seem to be two forces or tensions at play here, reflecting more general trends. On the one hand, we see a broadening of coverage, evidenced in having to deal with a wider range of media and content (print and digital; published and in-house; data, information and knowledge) and in providing a wide array of information services and user support (for example, advice, guidance, instruction, searching and analysis), often to a diverse clientele. On the other, we see a development in the technical content of the work, requiring higher levels of specialism and in-depth knowledge of the subject field and its business or other context. This pattern confirms research at the University of Bristol on professional roles in general, which pointed to higher levels of work, greater business involvement and more networking within teams. ${ }^{30}$

Figure 1 is an adaptation of a US model of the 'cyberinfrastructure' revolution. ${ }^{31}$ It asserts that the information profession is expected to deliver more functionality at higher capacity, in line with the increased technological capability at its disposal.

\section{Figure 1 Broadening and deepening professional capability}

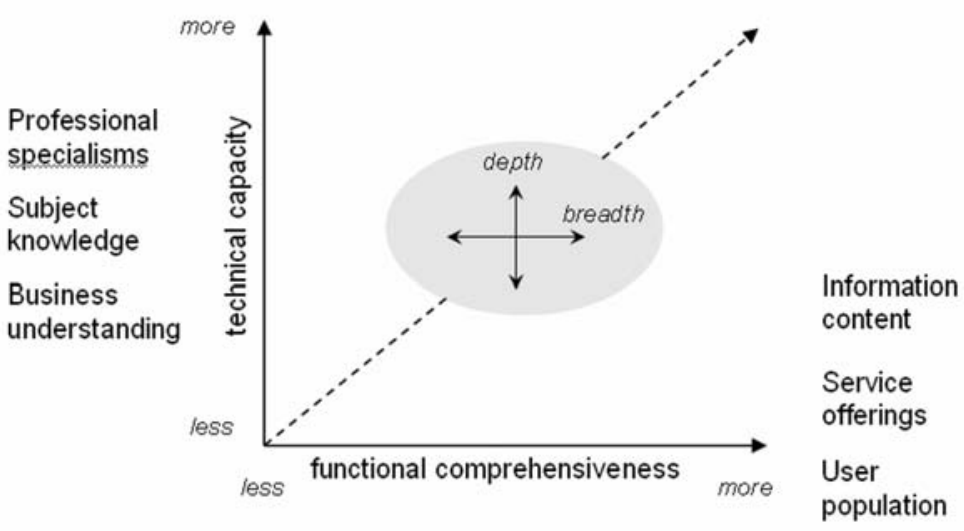

This suggests a possible divergence in future information career paths, with technical specialists developing, managing and supporting the 'infostructure' (information infrastructure) and functional specialists aligning information with business and personal needs and applying information solutions to client problems. Research in the US has already suggested this scenario for Information Systems (IS) professionals. ${ }^{32}$ One question here is how this work will be divided between information specialists, IS/ICT professionals and other professionals with information-oriented backgrounds, interests and expertise: how will information-intensive work be spread across the 'information continuum'?

\section{Expanding skills - specialists and generalists}

There have been several UK government-sponsored studies of skills needs and development priorities for the library and information sector over the past decade. The information services National Training Organisation (isNTO) carried out 'skills foresight' 
exercises in 2000-01 and 2002-03, investigating the views of employers from libraries, archives, records and information/knowledge management organisations. ('Skills' here covers the whole set of knowledge, skills and other attributes required for effective performance.) Both reports highlighted the wide range of skills required and ranked management and personal skills as slightly more important than 'job-related' (professional/technical) skills. Leadership and ICT competence were priority areas in both studies. Other development needs included customer care; "skills which relate to the social inclusion agenda, such as guidance and counselling, languages, cultural awareness"; managing change and "strategic and practical skills required...to become more outward looking and proactive". ${ }^{33,34}$

The consultancy firm TFPL has carried out three relevant studies, investigating skills requirements for working in the corporate sector and in knowledge management environments (sponsored by the British Library Research and Innovation Centre, the Library and Information Commission and the isNTO). Research in the corporate sector concentrated on requirements for first and second posts and identified four interpersonal 'soft' skills (team working, oral and written communication, listening/questioning and time management) as key needs, alongside professional skills in online searching and 'business focus' - understanding and maximising the value of information professionals to the business. ${ }^{35}$

TFPL investigated the skills needed for knowledge management through a broadlybased international study in 1998-99 and through eight sector-specific UK case studies in 2000-01. These studies also identified business and organisational (contextual) understanding as a key requirement for KM roles, together with the personal attributes of ambition and risktaking, and the professional capacity to shift from a service focus and support-function mindset to being a strategic player and equal partner in the organisation.

The first KM report categorised skills and competencies as 'core', 'survival' and 'enabling', while noting that the allocation of skills to categories might vary for different professions involved. ${ }^{36}$ The second study confirmed earlier findings and also reinforced the isNTO message that library and information professionals need to become "more outward looking and proactive". This report also emphasised the need for professionals to blend 'specialised skills' with generic (transferable) skills and 'business critical competencies'. It provided another categorisation of skills into three groups with subdivisions:

- $\quad$ People skills

○ personal attributes

$\circ \quad$ interpersonal and people management skills

- $\quad$ Business skills

○ organisation specific

○ transferable

- $\quad$ Expertise

○ information related skills (content)

○ information technology related skills. ${ }^{37}$

These studies place the specialist skills of professionals in their broader context and stress the need for professionals to develop generic and context-related skills in order to exploit their specialist skills effectively. The reports do not provide much guidance on priorities for developing specialist skills, although computer literacy and technology-related competencies emerge as important and (sometimes) urgent areas. 


\section{Librarians as technologists}

The need for library and information professionals to gain competence in ICT is a recurring theme in professional literature. According to Fourie, "IT skills are of course nonnegotiable", ${ }^{12}$ but this prompts the question, what kind of IT skills? For specialist roles, such as the 'digital librarian' envisaged by Hastings and Tennant ${ }^{38}$ and Sreenvisulu, ${ }^{39}$ staff evidently need competencies in markup languages, imaging technologies, optical character recognition, programming, etc., but for other 'hybrid library' roles, the technical skills will surely reflect the nature of the particular role and its context. Thus Kwasik found that US serials librarians were increasingly expected to be familiar with metadata standards and markup languages; ${ }^{23}$ but for many public librarians the technical requirement may be at a relatively basic level, such as skills in using standard office tools, searching databases and the Internet.

Thorhauge comments on the challenge of upskilling an ageing public library workforce in Denmark. He sees two further requirements beyond just understanding and handling the new technology: ability to handle the changing needs of users, by providing ICT training or consultancy-like services, and ability to handle strategic development, including cultural change. ${ }^{40}$ Other authors recognise that technology-related requirements extend beyond technical skills to contextual understanding: Battin specifies as important proficiencies an understanding of the capacities of digital technologies and of the way that different disciplines use them ${ }^{41}$ and Johnson suggests that rather than teaching specific systems, professional education should develop transferable skills in students by:

- $\quad$ giving them an understanding of the underlying principles,

- $\quad$ accustoming them to using manuals for self-instruction when introducing new systems,

- $\quad$ demonstrating how systems might be applied in professional practice,

- $\quad$ providing a level of technical understanding, sufficient to discuss systems confidently with vendors and technical experts,

- $\quad$ enabling them to recognise what the technology is capable of doing, sufficient to plan and manage changes in information provision.

\section{Librarians as teachers}

As indicated earlier, training/teaching is another key area for competency development. The CILIP report on the health sector identified teaching as the most expanded and changed activity, ${ }^{9}$ confirming Scherrer's findings in the US. ${ }^{42}$ Librarians in the education sector have a long tradition of providing user education/bibliographic instruction, but educational and technological changes have broadened this role to embrace information literacy in the digital environment and extended the modes of delivery to include interactive online tutorials, such as the Internet Detective, ${ }^{43}$ as well as point-of-need instruction and timetabled classes. According to Braun, the change has been equally profound for many public libraries, who have often moved from doing no training at all to providing both on-thespot and classroom-based training on a wide range of technology-related topics, including teaching the basics of computing (using a mouse, word processing, etc). ${ }^{21}$

Many practitioners have argued for a step-change in competency for librarians to fulfil teaching roles properly. Barrett calls for a new specialist certificate in school librarianship to cover topics such as pedagogical theory, teaching and learning styles, and the national curriculum. ${ }^{44}$ Peacock argues that "the knowledge and skills required to formulate and deliver effective teaching and learning experiences must take an essential, rather than desirable, place in the librarian's portfolio". She itemises the range of pedagogical, strategic (interpersonal and organisational) and information-related skills and competencies needed to move from 
'librarians who teach' to educators and learning facilitators. ${ }^{45}$ Bell and Shank use the term 'blended librarian' to make the case for an academic librarian who "combines the traditional skill set of librarianship with the information technologist's hardware/software skills, and the instructional or educational designer's ability to apply technology appropriately in the teaching-learning process". ${ }^{17}$

\section{Reframing competence - statements and models}

The maintenance of competence through Continuing Professional Development (CPD) is one of the defining characteristics of a professional person and CPD has become even more important in the fast-moving environment of the $21^{\text {st }}$ century. Many professional bodies now operate mandatory or voluntary schemes to validate CPD of their members. CILIP introduced a voluntary revalidation scheme in 2005 , which may eventually become mandatory. ${ }^{46}$ In this context, professionals need to be more conscious and systematic in managing and appraising their own development, as well as in facilitating the development of the staff they manage.

At the same time, many governments have recognised the contribution of skills development to national competitiveness in a global economy and have identified sets of key skills or competencies, which the education system must develop to prepare students for employment. ${ }^{47,48,49}$ The focus is now moving beyond skills for employment to the concept of employability, that is "the capability to move self-sufficiently within the labour market to realise potential through sustainable employment". ${ }^{50}$ In the UK, this has led to mandatory Personal Development Planning (PDP) for students in higher education, which the Quality Assurance Agency (QAA) defines as "a structured and supported process undertaken by an individual to reflect upon their own learning, performance and/or achievement and to plan for their personal, educational and career development". 51

Thus both students and practitioners of library and information science (LIS) need to manage, monitor and reflect on their personal professional development. The development needs of these two groups obviously vary, particularly in terms of the level of skills and depth of knowledge required, but they should be working within a common overarching model of professional competence and, ideally, a competency model that will support them from initial professional education not only to their first professional post and full membership of their professional body, but also through CPD to higher-level posts, revalidation and senior grades of professional membership.

To support CPD effectively, such a model needs to be holistic in scope, representing the full range of skill and competency areas identified in studies of workforce development needs. It also needs to be hospitable in nature, taking account of the fluid qualities of information work and its boundaries with other professions. The next question is whether any existing competency models, frameworks or documents meet these needs or could be adapted to do so? The following sections consider a sample of possible candidates from the UK and US.

\section{UK frameworks}

Possible UK candidates include the QAA 'subject benchmark statement' for LIS education, the CILIP accreditation instrument for LIS courses and the PDP tool developed by the Learning and Teaching Support Network for Information and Computer Sciences (LTSNICS). The QAA statement contains two main sections on subject knowledge, skills and understanding (20 items) and general transferable skills (33 items) ${ }^{52}$ It covers the specialist knowledge areas effectively, but there is significant overlap between items here and those in the general section, which gives a confusing picture. Also, the general section needs further 
development to cover the full range of management and business competencies required in the workplace.

The CILIP instrument has five main categories, of which four are information-related, with the fifth covering management and transferable skills. The allocation of both information-related and management-related items to categories is somewhat arbitrary. For example, some management competencies (such as strategic planning and marketing) are listed under Information Management and Organisational Context, instead of being in the final section, thus presenting these competencies as specialist information capabilities rather than generic ones. ${ }^{53}$

The PDP tool is aimed at students, graduates and "professionals within the ILS industry who wish to develop and maintain a Continuing Professional Development (CPD) record”. It covers 53 skills under 14 headings, grouped as three skill sets - key skills, personal skills and professional skills. Here again the relationship of items to headings is often questionable: the distinction between 'key' and 'personal' skills seems artificial; there is overlap between the heading Organisational Management in 'personal skills' and the heading Information Service and Organisations Management in 'professional skills'; and the 'professional skills' include a mix of information-related and general management competences, with project management arbitrarily listed under Information Systems, instead of being seen as a generic ability.

This tool provides four 'statements of competence' for each skill, intended to correspond respectively with the start, duration and completion of the LIS degree and progression towards chartered membership of CILIP. However, many of the defined levels of competence depict stages of development that do not seem to reflect the real world. Moreover, offering only four levels gives an unduly limited picture of professional competence and reduces the value of the tool for CPD. ${ }^{54}$ Several models from other domains provide more levels, notably the Skills Framework for the Information Age (SFIA) promoted by the e-skills UK national training organisation, which defines seven levels of responsibility, progressing from basic entry to senior management, and covers both specialist and nonspecialist jobs for the IS/ICT field. ${ }^{55}$

\section{US frameworks}

Another approach to articulating professional competence is by the development of formal statements of competencies required for particular professional roles. This practice is long established in the US, notable examples including the Competencies for Librarians Serving Youth (first published in 1981) and the Competencies for Librarians Serving Children in Public Libraries, in addition to the widely-cited SLA Competencies for Information Professionals of the $21^{\text {st }}$ Century. Such documents have a role in facilitating CPD, supporting recruitment and promoting the profession.

The youth and children's librarianship statements from the American Library Association each list around 60 competencies arranged under seven headings. Although they focus specifically on youth library work, they provide a more coherent view of professional competence than the UK documents examined, with more effective differentiation of specialist and generic competencies, but their discursive style does not enable rapid assimilation of the full spectrum of attributes covered. ${ }^{56,57}$

The SLA Competencies provide a case study in the evolution of professional thinking about what constitutes and defines the library and information profession, and how best to present its essential and unique attributes. The original version presents specialist information-related and generic management abilities together as Professional Competencies, but the latest edition has a clearer breakdown under four headings: Managing Information 
Organizations, Managing Information Resources, Managing Information Services and Applying Information Tools and Technologies. However, two other changes seem less satisfactory: the omission of "specialized subject knowledge appropriate to the business of the organization or client" and the relegation of instruction for service users/education in information literacy from a competency to an example ('applied scenario') in the revised version. $^{58,59}$

\section{New models}

This brief review has identified a failure, particularly in UK frameworks, to differentiate between specialist information-related and transferable generic skill sets. US competency documents provide a more coherent view of professional competence, but their layout and length make it hard to gain a quick overview of the field. Figure 2 presents an integrated high-level model of professional competence for the library and information field, which reflects published findings on development needs and draws particularly on the TFPL studies of knowledge management environments.

\section{Figure 2 Differentiating and contextualising professional competence}

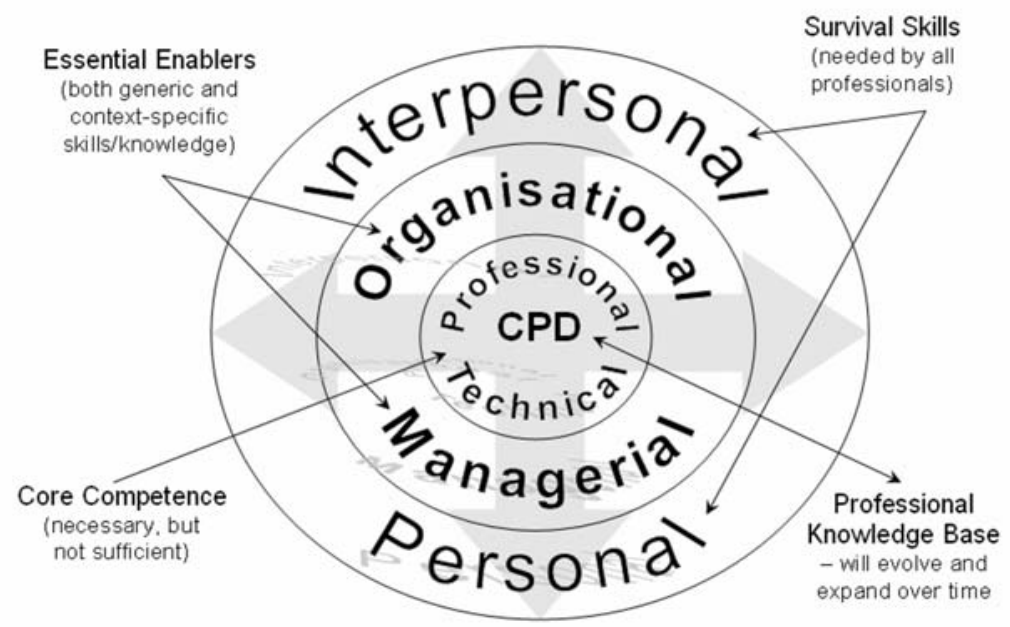

This model aims to show that all professionals need a complex mix of specialist, generic and contextual competencies. The concentric circles show how specialists need to surround and augment their core Professional/Technical competencies with essential businessrelated and supporting (inter)personal competencies for effective performance. The middle circle deals with the need for 'business acumen'. It includes both generic transferable Managerial competencies (such as strategic planning and marketing) and context-specific Organisational competencies, related to the particular company, institution or community where the professional works (understanding of its structure, culture, subject field, etc.). The outer circle covers Personal attributes and skills (such as time management) as well as Interpersonal skills (such as team work). 
Research cited above suggests that professionals need to develop and promote their understanding of the specific business context in which they work, as well as their generic abilities, to achieve success in evolving and fluid organisational structures. Their professional/technical knowledge base will evolve and expand to reflect both the development of the profession in its environment and the development of individuals in their careers. A key issue here is how to deal with the blurring and overlap of boundaries between different professions (such as librarians and teachers). The Bristol work cited earlier noted that in addition to professional, business and personal skills, professionals are increasingly expected to have cross-functional skills, to enable them not only "to negotiate and communicate with other professionals", but also "to make decisions outside the immediate confines of their original specialism". ${ }^{30}$

One way of representing this would be to insert another circle in the model above between the core and enabling competencies to cover Cross-Functional Capabilities. However, this would make the diagram complicated and may still not capture the complexities of the situation at a sufficiently detailed level to be useful. Figure 3 is an expanded view of the core competence of library and information work, giving an academic library perspective on the blurring of boundaries with other areas.

\section{Figure 3 Evolving and overlapping professional specialisms}

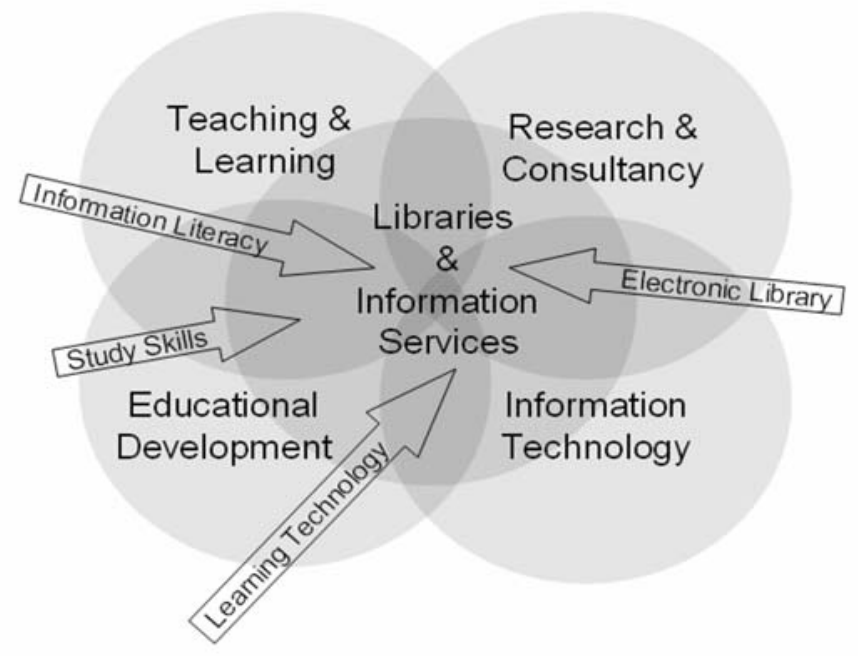

This model shows how library and information competencies are increasingly overlapping with competencies in teaching and learning, research and consultancy, information technology and educational development and also indicates emergent boundaryspanning specialisms. Its main aim is to help make sense of the field, but it also has a potential role in identifying professional development needs and partners.

\section{Conclusion}

Technological, organisational and educational changes are significantly affecting the library and information profession. There is a mixed picture of role development, with 
technology incorporated into existing functions, significantly complicating some jobs and also generating new specialisms. The integration of information into business activities is blurring the traditional boundaries between information, IS/ICT and other professionals, including teachers. Demands to broaden and deepen capacity suggest a divergent model of roles with technically specialised and business oriented dimensions.

The skill set for the network world includes strategic business and soft personal skills in addition to specialist information skills. Professional competence is multi-faceted, requiring generic and context-specific knowledge and understanding related to particular roles. Competence in ICT is a core requirement, but needs to include user knowledge and strategic awareness as well as practical skills. Staff who teach need practical skills, theoretical knowledge and contextual awareness to fulfil this role.

Many existing professional competency frameworks fail to differentiate specialist and generic skill sets and do not articulate the range and nuances of competencies needed. Highlevel models can help to identify, develop and promote professional capabilities in a changing situation. More work is needed to:

- $\quad$ explore the convergence and divergence of roles in information management,

- $\quad$ articulate fully our core competencies in a technologically rich environment,

- $\quad$ investigate and define different levels of information-related competencies for information-specialist and other information-intensive activities.

\section{References}

${ }^{1}$ Castells, M. The Internet Galaxy: Reflections on the Internet, Business and Society. Oxford: Oxford University Press, 2001.

${ }^{2}$ Ward, S. Information professionals for the next millennium. Journal of Information Science 1999, 25 (4), 239-247.

${ }^{3}$ Lynch, C. From automation to transformation: forty years of libraries and information technology in higher education. EDUCAUSE Review 2000, 35 (1) 60-68. URL

<http://www.educause.edu/pub/er/erm00/pp060068.pdf>

${ }^{4}$ Johnson, I.M. Catching the tide: environmental pressures for an emphasis on management in the library and information sciences curriculum. Library Management 1999, 20 (6), 317-331.

${ }^{5}$ Hirshon, A. Integrating Computing and Library Services. Boulder: CAUSE, 1998. CAUSE Professional Paper Series, \#18

${ }^{6}$ Field, C. Theory and practice: reflections on convergence in United Kingdom universities. Liber Quarterly 2001, 11 (3), 267-289.

${ }^{7}$ Sayers, R. Open relationships, de-facto marriages, or shotgun weddings?: the convergence and integration of libraries and computing/information technology services within Australian universities. Australian Library Journal, 2001, 50 (1), 53-71. URL

$<$ http://archive.alia.org.au/alj/50.1/full.text/open.relationships.html>

${ }^{8}$ Coleman, A. Interdisciplinarity: the road ahead for education in digital libraries. D-Lib Magazine 2002, 8 (7/8). URL <http://www.dlib.org/dlib/july02/coleman07.html>

${ }^{9}$ Chartered Institute of Library and Information Professionals. Future proofing the profession: the report of the Health Executive Advisory Group to the Executive Board of CILIP. 2004. URL <http://www.cilip.org.uk/professionalguidance/health/heagfinalreport.htm>

${ }^{10}$ Levy, P., Ford, N., Foster, J., Madden, A., Miller, D., Nunes, M.B., McPherson, M. \& Webber, S. Educational informatics: an emerging research agenda. Journal of Information Science 2003, 29 (4), 298-310.

${ }^{11}$ McKnight, S. Managing cultural change: the challenge of merging library services, curriculum development and academic professional development. IFLA Journal 2002, 28 (5/6) 266-72. URL <http://www.ifla.org/V/iflaj/art280506.pdf> 
${ }^{12}$ Fourie, I. Librarians and the claiming of new roles: how can we try to make a difference. Aslib Proceedings 2004, 56 (1), 62-74.

${ }^{13}$ Cheng, G. The shifting information landscape: re-inventing the wheel or a whole new frontier for librarians. New Library World 2001, 102, 1160/1161, 26-33.

${ }^{14}$ Homann, B. German libraries at the starting line for the new task of teaching information literacy. Library Review 2003, 52 (7), 310-318.

${ }^{15}$ Chochrek, D. Market the value of your competitive intelligence: an added role for the information center. Information Outlook 2000, 4 (2), 32-35.

${ }^{16}$ Choo, C.W. Working with knowledge: how information professionals help organisations manage what they know. Library Management 2000, 21 (8), 395-403.

${ }^{17}$ Bell, S.J. \& Shank, J. The blended librarian: a blueprint for redefining the teaching and learning role of academic librarians. College \& Research Libraries News 2004, 65 (7), 372375.

${ }^{18}$ MacColl, J. Virtuous learning environments: the library and the VLE. Program 2001, 35 (3), 227-239.

${ }^{19}$ Ashworth, S., Mackie, M. \& Nixon, W.G. The DAEDALUS project, developing institutional repositories at Glasgow University: the story so far. Library Review 2004, 53 (5), 259-264.

${ }^{20}$ Jones e-global library. The Role of Librarians in the Digital Age [n.d.] URL

$<$ http://www.jonesknowledge.com/eglobal/ala_survey_download.html >

${ }^{21}$ Braun, L.W. New roles: a librarian by any name. Library Journal 2002, 127 (2), 46-49.

${ }^{22}$ Sharp, K. Internet librarianship: traditional roles in a new environment. IFLA Journal 2001, 27 (2), 78-81. URL <http://www.ifla.org/V/iflaj/art2702.pdf>

${ }^{23}$ Kwasik, H. Qualifications for a serials librarian in an electronic environment. Serials Review 2002, 28 (1), 33-37.

${ }^{24}$ Chartered Institute of Library and Information Professionals. CILIP in the Knowledge Economy: A Leadership Strategy: The Report of the Competitiveness and the Knowledge Based Economy Executive Advisory Group to CILIP. London: CILIP, 2002. URL $<$ http://www.cilip.org.uk/professionalguidance/knowledgeeconomy>

${ }^{25}$ Griffiths, P. Managing your Internet and Intranet Services. London: Library Association Publishing, 2000.

${ }^{26}$ Wherry, T.L. The Librarian's Guide to Intellectual Property in the Digital Age. Chicago: American Library Association, 2002.

${ }^{27}$ Kuhlthau, C.C. \& Tama, S.L. Information search process of lawyers: a call for 'just for me' information services. Journal of Documentation 2001, 57 (1), 25-43.

${ }^{28}$ Krauss-Leichert, U. The multimedia sector: new fields of activity for information specialists. IFLA Journal 2001, 27 (3), 163-70. URL

<http://www.ifla.org/V/iflaj/art2703.pdf>

${ }^{29}$ Lachance, J.R. Beyond competencies: the journal from relevance to mission-critical. In: Online Information 2004 Conference Proceedings, 2004, 131-36. URL <http://www.onlineinformation.co.uk/2004proceedings/thursam/lachance_j.pdf >

${ }^{30}$ Watkins, J., Drury, L. \& Preddy, D. From Evolution to Revolution: The Pressures on Professional Life in the 1990s. Bristol: University of Bristol, 1992.

${ }^{31}$ United States. National Science Foundation. Blue-Ribbon Advisory Panel on Cyberinfrastructure. Revolutionizing Science and Engineering Through Cyberinfrastructure. Arlington, Va.: NSF, 2003. URL <http://www.communitytechnology.org/nsf_ci_report/> ${ }^{32}$ Lee, D.M.S., Trauth, E.M. \& Frawell, D. Critical skills and knowledge requirements of IS professionals: a joint academic/industry investigation. MIS Quarterly 1995, 19 (3), 313-340. 
33 information services National Training Organisation. Skills foresight in the information services sector 2000-2007. Bradford: isNTO, 2001.

${ }^{34}$ information services National Training Organisation. Skills foresight in the information services sector 2003-2009. Bradford: isNTO, 2003.

${ }^{35}$ Stenson, A., Raddon, R. \& Abell, A. Skills and Competencies in the Corporate Sector. London: British Library Research and Innovation Centre, 1999. British Library Research and Innovation Report 162.

${ }^{36}$ TFPL Ltd. Skills for Knowledge Management: Building a Knowledge Economy: A Report .

.. Based on Research Jointly Funded by TFPL and the Library and Information Commission. London: TFPL, 1999.

${ }^{37}$ Skelton, V. \& Abell, A. Developing Skills for the Information Services Workforce in the Knowledge Economy: A Report on the Outcomes of Eight Scenario Planning Workshops, Commissioned by the Information Services National Training Organisation. London: TFPL Ltd., 2001. Library and Information Commission Research Report 122.

${ }^{38}$ Hastings, K. \& Tennant, R. How to build a digital librarian. D-Lib Magazine 1996, 2 (11). URL <http://www.dlib.org/dlib/november96/ucb11hastings.html>

${ }^{39}$ Sreenivasulu, V. The role of a digital librarian in the management of digital information systems. The Electronic Library 2000, 18 (1), 12-20.

${ }^{40}$ Thorhauge, J. New demands: old skills. World Library and Information Congress: 70 th IFLA General Conference and Council, 2004. URL $<$ http://www.ifla.org/IV/ifla70/papers/053e-Thorhauge.pdf>

${ }^{41}$ Battin, P.M. Librarianship in the twenty-first century. Syracuse University Library Associates Courier 1998-2001, XXXIII, 43-61.

${ }^{42}$ Scherrer, C.S. Reference librarians' perceptions of the issues they face as academic health information professionals. Journal of the Medical Library Association 2004, 92 (2), 226-232.

${ }^{43}$ Internet Detetective. URL <http://www.sosig.ac.uk/desire/internet-detective.html>

${ }^{44}$ Barrett, L. Skills provision and development for school librarians. In: information services National Training Organisation. Workforce Development Plan. Bradford: isNTO, 2002, 5.

${ }^{45}$ Peacock, J. Teaching skills for teaching librarians: postcards from the edge of the educational paradigm. Australian Academic \& Research Libraries 2001, 32 (1), 26-42. URL $<$ http://www.alia.org.au/publishing/aarl/32.1/full.text/jpeacock.html>

${ }^{46}$ Chartered Institute of Library and Information Professionals. Revalidation Scheme Handbook. London: CILIP, 2004. URL

$<$ http://www.cilip.org.uk/qualificationschartership/FrameworkofQualifications/revalidation> ${ }^{47}$ United States. Department of Labor. Employment \& Training Administration. Secretary’s Commission on Achieving Necessary Skills. What Work Requires of Schools: A SCANS Report for America 2000. Washington, DC: US Department of Labor, 1991. URL $<\mathrm{http}$ //wdr.doleta.gov/SCANS/whatwork>

${ }^{48}$ Key Competencies: Report to the Committee to Advise the AEC and Ministers of Vocational Education, Employment and Training on Employment Related Key Competencies. Canberra: Australian Education Council, 1992 (Mayer report). URL $<$ http://www.detya.gov.au/nbeet/publications/pdf/92_36.pdf >

${ }^{49}$ Dearing, R. Review of Qualifications for 16-19 Year Olds. Hayes: School Curriculum and Assessment Authority, 1996.

${ }^{50}$ Hillage, J. \& Pollard, E. Employability: Developing a Framework for Policy Analysis. Brighton: Institute for Employment Studies, 1998. DfEE Research Brief No. 85 [WWW document]. URL < http://www.employmentstudies.co.uk/summary/summary.php?id=emplblty> 
${ }^{51}$ Quality Assurance Agency for Higher Education. Policy Statement on a Progress File for Higher Education. Gloucester: QAA, 2000. URL

<http://www.qaa.ac.uk/crntwork/progfilehe/guidelines/policystatement/contents.htm>

${ }^{52}$ Quality Assurance Agency for Higher Education. Academic Standards - Librarianship and Information Management. Gloucester: QAA, 2000. Subject Benchmark Statements. URL <http://www.qaa.ac.uk/crntwork/benchmark/librarianship.html>

${ }^{53}$ Chartered Institute of Library and Information Professionals. Accreditation Instrument: Procedures for the Accreditation of Courses. rev. ed. CILIP, 2002 [Unpublished document]. ${ }^{54}$ Beckett, I. \& Brine, A., (comps.) Recording Skills Development for Information and Library Science: Developed from the Recording Academic, Professional and Individual Development (RAPID) Progress File at Loughborough University. Loughborough: LTSNICS (Information Science), 2002. URL <http://www.ics.ltsn.ac.uk/ILS/RAPIDskillsrecord.pdf> ${ }^{55}$ Introducing SFIA. London: SFIA Foundation, [n.d.]. See also the SFIA Foundation website. URL <http://www.sfia.org.uk/>

56 American Library Association. Young Adult Library Services Association. Young Adults Deserve the Best: Competencies for Librarians Serving Youth. Chicago: ALA, 2003. URL $<$ http://www.ala.org/ala/yalsa/professionaldev/youngadultsdeserve.htm>

${ }^{57}$ American Library Association. Association for Library Service to Children. Competencies for Librarians Serving Children in Public Libraries. rev. ed. Chicago: ALA, 1999. URL $<$ http://ala.org/ala/alsc/alscresources/forlibrarians/professionaldev/competencies...

${ }^{58}$ Special Libraries Association. Special Committee on Competencies for Special Librarians. Competencies for Special Librarians of the 21 st century. Washington: SLA, 1997.URL <http://www.sla.org/content/learn/comp2003/97comp.cfm>

${ }^{59}$ Special Libraries Association. Special Committee on Competencies for Special Librarians. Competencies for Information Professionals of the 21 st Century. rev. ed. Washington: SLA, 2003.URL <http://www.sla.org/content/learn/comp2003/index.cfm> 